\title{
Wholesaling, the Role of the Middleman and Marketing Costs: Some Forgotten Concepts in Marketing Thought
}

\author{
Dr. Robert Tamilia \\ École des Sciences de la Gestion \\ Université du Québec à Montréal (UQAM) \\ Dr. Sylvain Charlebois \\ Faculty of Business Administration \\ University of Regina \\ 3737 Wascana Parkway \\ Regina, Saskatchewan S4S 0A2 \\ Tel: 306-585-4111_E-mail: sylvain.charlebois@uregina.ca
}

\begin{abstract}
Most introductory or intermediary marketing courses present marketing from a manufacturer's perspective, in which product distribution is treated as one of the marketing mix variables under the complete control of the manufacturer. Product distribution is assumed by a wide range of middlemen and various distribution agencies that operate in a distinct and separate market. Wholesaler - distributors represent one such type of middlemen and their marketing agenda do not always coincide with the one set out by manufacturers. Thus, the need to form partnerships or alliances via the use of marketing programs and other incentives in order to assure smooth product distribution from points of the production to end users. This paper, then, briefly explains the role of wholesaler-distributors in general, and specifically spells out what they actually do for their suppliers based on the types of marketing functions they perform. The functional approach is also used to analyze the various marketing tasks which are assumed by the wholesaler when taking on a new supplier's product line.
\end{abstract}

Keywords: Wholesaling, middleman, Logistics, product life cycle, Role of wholesalerdistributors, Marketing channels 


\section{Introduction}

Distribution is not a well understood domain of the marketing discipline, especially by academics. Pricing strategies, product development and promotional strategies, the other Ps, seem to have been the main focus for decades. This is quite ironic given that distribution and the tasks performed by distributors in our market economy was what led to the birth of marketing as an academic discipline in the early 1900s (Bartels 1962). In fact, prior to the adoption of the term "marketing" in the literature, marketing was known as "distribution" (Lichtenthal and Belk 1984).

For purposes of this paper, a distributor, a wholesaler or a wholesaler-distributor is defined as a merchant middleman who resells products purchased from manufacturers and others to institutional, commercial or even industrial customers. Industrial distributors are considered here as merchant wholesalers. In general, a wholesaler or a distributor will carry inventory, have one or more warehouses, employ sales personnel, and may possess its own transportation facilities. Wholesaling is also very prominent in the service sector as well.

\section{The Marketing Role of Distributors}

In general, distributors perform numerous marketing and managerial tasks on behalf of their suppliers at a much higher level of efficiency and effectiveness than if these tasks were performed by manufacturers themselves. In other words, distributors are specialized businesses in the market which can lower operating costs for manufacturers. As specialized middlemen, they can achieve economies of scale. Their know-how allows a manufacturer to transfer to them the performance of those channel functions with which they excel. It can even be argued that a necessary but not sufficient condition for a market to become viable rests upon the marketing job done by distributors.

An interesting way to understand the role of distributors is to picture a market as being made up of many buyers and sellers. These buyers and sellers cannot make contact because they are too many separations which exist between them in the market. These market separations, or what McInnes (1964) called gaps, need to be resolved if buyers and sellers are to be satisfied. For example, time, information, space, financing, price, inertia, product performance, service, product assortment, values and beliefs are some of the market separations which prevent buyers and sellers from realizing what each want in the market.

These separations may well prevent producers from selling their goods to end users. After all, manufacturers are geographically separated from their end users. Also, products cannot always be produced at the exact time, place, quantity and assortment desired by customers. Customers do not always have all the necessary funds to purchase a product. Distributors, therefore, step in to close many of these market gaps and realize sales. By performing the marketing functions, distributors are able to bring products closer to where customers are located, which permit them to fulfill orders on demand due to the proximity of their warehouses which stock an assortment of goods.

In general, distributors are better equipped than their suppliers to perform various marketing tasks not only because they are closer to end users but also because they offer costs advantages 
that their suppliers do not have (Kimanyi 2005). The specialized set of functions they provide whether in warehousing or extensive market coverage can result in economies of scale that only they could achieve. For example, a distributor will normally buy in large lots (full carloads or containers). Transportation, handling and shipping costs are much lower per unit than if the supplier had to sell a few units to a large number of end users. In fact, a supplier would only need to process one order instead of hundreds or even thousands if the supplier had to deal directly with end users. A supplier would only need to make one market contact instead of ten in order to reach ten customers. The reduction in the number of market contacts due to the presence of a wholesaler represents major costs savings for each supplier. In addition, product assortment convenience which characterizes a distributor (and not a supplier) implies that fixed costs are spread over a wider assortment of products than would be the case for suppliers.

Adam Smith recognized long ago that the division of labor and specialization of tasks increase market efficiency. That is exactly what distributors do. Specialization makes them better suited to assume certain marketing tasks. And the job they do helps producers lower their costs of doing business. Now exactly what do distributors do? That is, what are the types of marketing tasks normally assumed by distributors? We have already seen that, in general, distributors make market contacts, handle and store goods, ship and deliver them, provide quantity and assortment convenience, offer before and after sales service, provide for the informational and financing needs of their buyers, and, of course, assume the necessary business risks associated with any transaction.

This list is by no means complete because some full-service distributors may actually offer more while limited or very specialized distributors may restrict their activities to the performance of just a few tasks. In general, some authors have suggested that only nine such functions or tasks exist (Beckman and Davidson 1967). McGarry (1950), on the other hand, has proposed that there are six major functions of marketing, these being the contactual, pricing, merchandising, propaganda, physical distribution, and finally, the termination functions. Others have argued that only twelve such functions exist (Rosenbloom 1987). Ever since distributors have been recognized as accomplishing marketing tasks, their numbers have ranged from 2 to over 35. The exact number need not concern us. Exhibit 1 outlines seven such functions. Each function listed is accompanied by a detail list of activities which are self-explanatory. It is obvious from the Exhibit that a distributor's job is much more than mere product distribution. The distributor buys the products from his suppliers in assortment and quantity sufficient to realize transportation economies. The distributor then becomes completely responsible for reselling these products in his assigned market. He assumes all the risks involved in reselling the products given that he now has title to the goods. If the market is all of Canada, then the distributor needs numerous warehouses strategically located and electronically linked together for fast order processing, shipping, billing and delivery. The distributor needs to hold sufficient inventory to avoid stockouts, and lost sales. Reordering from suppliers needs to be made in a timely fashion: not too late to avoid stockouts and not too early to avoid increase inventory holding costs. In fact, the distributor's job is more than just being involved in logistics (Gummesson 2002). The distributor acts as if he was assuming his suppliers' marketing responsibilities in his assigned territories. He needs to make as many sales contacts as possible 
in order to generate sales. In fact, he becomes much more knowledgeable about local market conditions, about buyer needs and local competition than the manufacturer could ever hope to achieve. The distributor needs to have the competence and technical skills not only to advise end users on how to use and maintain products, but to repair and even modify them in some cases. It is as if a distributor also needs engineering and research and development facilities in order to satisfy both end users and suppliers as well.

In summary, distributors provide an essential set of economic services for their suppliers. In the next section we will review some of the costs related to distributors' marketing tasks.

\section{The Costing of Marketing Tasks}

It is easy to understand why distributors are great facilitators in realizing sales because of their abilities to perform the marketing tasks that a manufacturer could not do or could not afford to do. It is no wonder that distributors occupy a pivotal role the distribution of suppliers' products.

One could argue that manufacturers could sell direct without the use of distributors. This would mean that the job of closing all of the market gaps would now be their responsibility. And as a result, their costs of doing business would increase accordingly.

When selling direct to customers, the various marketing tasks needed to bring products to the market must now be assumed by manufacturers. The marketing tasks or the closing of market gaps are not eliminated when there are no distributors. These tasks are merely shifted back to the manufacturer. The shiftability of marketing tasks from one end in the channel of distribution to another (i.e., from distributors to manufacturers or vice-versa) makes it very difficult to calculate their exact costs. Cost accounting procedures designed to allocate specific costs at every step of the production process cannot be duplicated for marketing or for distributive activities. The very nature of marketing tasks makes it rather difficult, if not impossible, to separate into neat accounting categories the various costs components involved in the marketing and distribution of products. After all, the marketing tasks performed by distributors are essentially economic services. In a seminal article written by Hollander (1961), he persuasively argues that the work done by marketing consists of intangibles that resist quantification... Since many of these (marketing) functions are concerned with intangibles, facile evaluation of marketing performance seems unlikely, and perhaps impossible even for the future (p. 24).

An additional point of why the costing of marketing tasks is so difficult is because many of the functions can be performed simultaneously by the same person. For example, sales people are involved in one way or another in the performance of all of McGarry's six marketing functions such as the marketing tasks of contacting a potential buyer, introducing a new product, providing technical assistance, arranging for financing and delivery, and closing the sale can all be done at the same time by the same person.

How can a distributor be capable of calculating all of the costs involved in introducing a new product line to the market when the sales personnel is responsible for a multitude of other sales-oriented tasks on an on going basis? Such are the realities of costing economic services. One would need to conduct time and motion studies. But the lack of repetitiveness and the 
great variability of such tasks make such studies very difficult.

\section{Logistical Costs}

The field of physical distribution (i.e., logistics) is probably the area in marketing which has achieved the most success in arriving at cost estimates of carrying out the various logistical functions. This work has been carried out over the last thirty five years and has involved the Distribution Research and Education Foundation of the National Association of Wholesaler-Distributors. The literature on the costing of physical distribution tasks reports that physical distribution activities represent, on the average, twenty percent of sales, with a range of ten to thirty percent depending on the industry (Hardy and Magrath 1988; Sharman 1984; Stock and Lambert 1987). The types of firms nearer to the thirty percent level are more likely to be distributors involved in the reselling of industrial and commercial products. On the other hand, these same studies report that, on the average, direct selling expenses account for five percent of sales with a range of one percent to 16 percent. The firms having the highest selling expenses are those involved in the marketing of specific consumer goods such as perfume or cosmetics. These studies point out that logistics costs, as a percent of sales, exceed the costs of direct selling by a factor of four.

The conclusion is that logistics costs represent a very substantial portion of the cost of doing business for the average wholesaler-distributor. By adding a new product line, the logistics costs are bound to increase at or near the level of thirty percent of sales. In fact, these costs may even be higher given the need to integrate the new line within the distributor's physical distribution system (Manolis, Gassenheimer and Winsor 2004; Webb 2004). After all, warehouse space has to be made available and modified to meet the physical requirements of the new line. Parts may require specialized bins and shelf location adjustments for easy access. The new line may require more or a different type of packing or packaging material necessary for shipping or handling. Specialized materials handling equipment may be necessary. Special handling instructions may need to be posted, at least initially, in the warehouse. Finally, if a wholesaler-distributor has more than one warehouse or has national distribution (instead of local or regional), these start-up logistical costs may actually need to be repeated for each warehouse.

By adding a new product line, a distributor is bound to increase not only his logistics costs but other costs as well, some of which can also be substantial, such as the costs of selling the new line. Selling costs include advertising and promotional expenses, sales training, manpower requirements, traveling and lodging, and many other costs as we have already shown in Exhibit 1.

\section{A Distributor's Start-Up Costs in Product-Line Additions}

The question one could ask is how much would it cost a distributor to add a new product line to his present product assortment? It is obvious from our previous discussion that there are costs but it would be very difficult to arrive at a precise dollar figure.

The food distribution industry is a good reference source towards an understanding of start-up costs in introducing a new product line to the market (Grunert and Ramus 2005). A food chain 
(i.e., a food distributor) will usually ask a supplier for slotting allowances. These fees are an outright cash disbursement the supplier must give to the food chain to help pay for the start-up costs involved in selling and distributing the product (Therrien 1989).

This amount does not include the supplier's costs of promoting and selling the product or the supplier's physical distribution costs involved in delivering the product to the chain's distribution center.

Given that the supplier's sales people need to be trained in order for them to convince each supermarket manager to buy the product, for example by helping to set up store displays or informing store employees about the product, one can see that the costs of selling a new food item can be many times more than the slotting fee. If we added all of the slotting fees and other start-up costs required to sell a new food item across all of Canada, the amount would no doubt be in the millions of dollars. In fact, some companies have reported paying between $\$ 300,000$ and $\$ 1.5$ million per new product and from one-third to almost one-half (Therrien 1989) their promotion budgets to cover these fees (Gundlach and Bloom 1998).

The practice of a supplier giving a fee to a food chain in order to secure shelf space is not new. What is new though is that food chains today are in a better position of charging the fee because shelf space is at premium due mainly to the doubling in the number of items stocked in a typical supermarket which went from 13000 to 26000 items over the last decade (Major 2006).

But the self-space rental fee paid by suppliers does not tell the whole story. These slotting allowances actually help pay for the many logistical tasks performed by the food chain on behalf of their suppliers. Following is a list of some of the logistical functions which are assumed by the entire food chain, from production to retailing. All these functions create interrelationship amongst organizations involved with supplying goods.

- $\quad$ finding space in warehouses

- $\quad$ redesigning store shelves

- $\quad$ notifying each selected store about the availability of the new product

- recovering the costs for entering the new product information in the chain's computerized information and retrieval system

- $\quad$ assuming all the risks involved in buying a new product

- absorbing the logistical order processing and shipping costs involved in distributing the product to individual stores

- recovering the inventory holding costs for the new product

- offering quantity and line assortments of the new product to match each store's demand requirements

- recovering sales forecasting costs and the cost of assigning each selected store's product allotment 
- recovering manpower costs involved in all phases of physical distribution

Of course, the distribution requirements of the supermarket industry do not correspond to the requirements of the industrial wholesaler - distributor industry. For one thing, the supermarket industry is much more dynamic and competitive with thousands of new products being introduced in the marketplace every year which is unlike the situation facing a typical wholesaler-distributor (Gras, N.S. B. 1939). As a result, a wholesaler-distributor does not obtain slotting allowances from his suppliers when assuming distribution of a new line similar to the practice which exists in the food distribution business. His start-up costs are, therefore, not recuperated when handling a new line. Yet the wholesaler-distributor's performance of marketing functions is very similar to what a food chain does, except that warehouse rental fees (i.e., space fees) are not collected from the supplier, and neither are product failure fees if the new line proves to be unsuccessful, or if the supplier decides to change his distribution partners.

\section{Start-Up Costs and the Product Life Cycle}

Another important feature which characterizes the supermarket industry but not a wholesaler-distributor has to do with the product life cycle. The product life cycle (PLC) for new food items, that is, the time period needed for a food item to be displayed on supermarket shelves, (i.e., the introductory or start-up stage), to gain sales (i.e., the sales growth stage), to reach a sales plateau (i.e., the maturity stage), and to experience a sales decline (i.e., the decline stage) does not correspond to the same time periods for an industrial product line handled by a wholesaler-distributor (Jensen 1982). For example, some items handled by supermarkets may have a PLC such that the introductory and sales growth stages can occur in less than one year. In fact, some food chains actually charge suppliers a failure fee if the new product does not reach a minimum sales target within three months (Therrien 1989).

The nature of the industrial or commercial goods market is such that the start-up phase may last many years. This is due in part to the complexity of the product itself, the expenses of replacing currently functioning products with newer ones, and the multiplicity of people involved in making the purchase decision. All of these factors, and there are many more, can extend the start-up phase considerably.

Research findings reported by Thorelli and Burnett (1981) have shown that the PLC behavior of some industrial products varied from three to ten years, the time needed for products to go from rapid growth to maturity. The length of the start-up phase was not analyzed. However, these results support the contention that the start-up phase may last anywhere from one to three years for the following reason. Unit profits only begin to appear during the later part of the growth phase. On the other hand, the start-up phase is one in which negative unit profits are generated. From a business investment perspective, there is a time limit on the amount of losses any firm (a supplier or a wholesaler - distributor) is willing to absorb before deciding to cease product distribution. It should be understood that this time period takes into account only the time in which products are actually in the distributor's hand. The time spent negotiating and arriving at a distribution agreement is not included (Day 1981).

The PLC is a conceptual framework originally developed to show that the sales pattern of 
products over time go through a set of distinct stages or phases in their market evolution. But what happens in the case when a product is not new? Can such a product be more than in one stage of the PLC? The answer is yes because the product may occupy a different stage depending on the market. Thus, a product can be considered in its start-up phase when the market is redefined. For example, the market may no longer occupy the same geographical boundaries (i.e., going local to national); or the end users may be in a different segment, that is they may represent a class of potential customers who are unlike regular customers in terms of their needs, their supply requirements, or their industrial or commercial affiliations (Day 1981).

Irrespective of how a market is reassessed, one thing is certain: the start-up phase is clearly evident for a national distributor who takes on a product never handled before. For him, the start-up costs are real and expensive. The logistics costs alone represent a major start-up cost component, as we have already discussed (Frazier and al. 1996). If we add all of the sales and promotional expenses a wholesaler-distributor incurs when introducing a line of products never handled before and/or introducing the line to a new class of buyers, it becomes evident why initial sales are insufficient to cover all of the start-up costs. In fact, the PLC supports this contention that sales achieved during the start-up phase are incapable of recovering the costs involved in marketing and distributing the product. In other words, during the length of the start-up phase, losses will be incurred by the distributor.

\section{Start-Up Costs and the Supplier - Distributor Partnership}

The addition of a line of products represents, in most cases, for a typical distributor a major investment and commitment. For example, when a distributor adds a product to an existing assortment of between 500 to 1000, the consequences on his balance sheet are much more significant than when a food chain adds one product to an already existing assortment which may reach 26,000 for some supermarkets. Given that the start-up phase may last anywhere from one to three years (as discussed previously), the national distributor knows beforehand that he will operate in the red during that period of time. As a result, this period is critical for the distributor and it requires close coordination and cooperation with his supplier.

It is highly improbable that the distributor would contemplate the possibility that the supplier would terminate the selling arrangement during the start-up phase. The distributor is far too busy prospecting, and making sales presentation, training his sales force, arranging for customer financing, stocking and sorting products and parts throughout the distribution systems, preparing sales aids, and so forth to even consider the possibility. After all, start-up costs represent an important marketing investment. And like any other investment, the payoffs can only be realized sometime in the near future (i.e., in three years or less).

A supplier's decision to terminate the selling agreement during the initial phase of the PLC goes against the very essence of what a supplier - distributor partnership is all about. After all, if a break is to occur, it should occur prior to the establishment of the selling and distribution arrangement. Both parties usually spend a lot of time, sometimes years, negotiating an agreement which is built on trust and to the mutual satisfaction of both. Breaking the relationship during the start-up phase makes no business-sense whatsoever. In fact, most supplier - distributor selling arrangements have a tendency to last a long time. Kotler (1976) 
states that the channel decision process is unlike any other in marketing. For example, while advertising, pricing, or marketing manpower decisions can be altered in the short-run, channel ones cannot because they involve the firm in relatively long-term commitments to other firms. Kotler goes as far as to state that the duration of commitment between a manufacturer and a distributor may require an initial contract which lasts as long as ten years. Beckman and Davidson (1967) are also of the same opinion that certain manufacturer - distributor selling arrangements should have an initial contractual obligation of up to five years, subject to renewal. Thus, we can easily surmise a situation in which a manufacturer is linked with a distributor for periods ranging from ten, fifteen, or even twenty years, or longer.

There is a very good reason, among others, why a distribution partnership can last so long. The switching costs can be so high that it does not pay for either party to seek a new partner. This is especially true in the distribution of industrial or commercial equipment. In fact, a supplier -distributor relationship is very much like a marriage. Of course, divorces do occur, and supplier - distributor relations do break down. For the manufacturer, a decision to terminate an agreement is very serious business, not only because it disrupts product distribution but the decision may also have legal ramifications. Hardy and Magrath (1988) state that wrongful dismissal of a distributor under current US antitrust law can be very costly:

A terminated middleman who takes the manufacturer to court and wins can recover three times the actual monetary damage, plus attorney's fees, and costs of litigation (p. 490).

A terminated middleman also suffers considerably not only because of the lost "of the equity they have developed in an area" (Hardy and Magrath 1988, p. 490), but also because the middleman must preserve its sales volume on the product category by switching its customers to substitute products and to preserve its reputation (p. 491).

Of course, the search for a substitute supplier involves costs and may never be realized in the short run. As far as damage to its reputation, a terminated middleman may actually suffer irreparable harm among certain customers that a substitute supplier, if one is found, could never hope to remedy.

According to Hardy and Magrath (1988), there is never an ideal time to dismiss a middleman. They present a number of situations in which it would be unwise to dismiss a middleman because it would be too disruptive. For example, it is probably unwise to terminate a key dealer in the midst of the selling season for a highly seasonal item or during the height of a contest to build sales... the timing of the termination should probably take into consideration the timing of events such as major industry-association meetings, national trade shows, or the launch of an important advertising campaign in highly visible media.

A very important situation in which a distributor termination notice should not take place is during the start-up phase of product distribution. Distributor dismissal during the start-up phase, therefore, is unwise, unjustified, maybe illegal, and is to be avoided.

\section{A Method to Calculate a Distributor's Marketing and Distribution Start-Up Costs}

As we have seen, sales and gross margins during the start-up phase are generated in amounts 
insufficient to cover all of the distributor's start-up marketing expenses. Exhibit 1 shows in detail all of the cost-producing marketing and logistical tasks involved in selling and distributing a product. In addition, we have discussed other costs that are supplementary to the routine work done by a distributor when a new line is added to the product assortment. These costs are incurred during the start-up phase when the warehouses have to be ready to accept the new line with all of the information and training requirements in place. Finding accurate and detailed marketing costs estimates for all of the work done would be very difficult as already discussed. However, it is possible to simplify this task by reducing to five the number of marketing-related cost components.

The first component deals with administrative expenses. The addition of a new product line for a distributor means that a certain amount of general and administrative expenses have to be allocated to it. Using a percentage of sales is not recommended because of low sales during this phase. A more appropriate procedure is to estimate fixed costs as a percentage of the total number of products or product lines handled. The second component is the logistics one. As far as estimating the costs of logistics, there is no reason why the thirty percent of annual sales already discussed cannot be used. In fact, this figure is entirely reasonable for the start-up phase because it includes not only the routine logistical work involved in distributing the product but also the extra costs required for the line's logistical set-up needs. Estimating the third component, the one which accounts for the direct selling expenses, presents a problem. Traveling, lodging, and other direct expenses related to sales cannot be estimated because of the difficulty of allocating such expenses to the new product line relative to the established ones, or to the new class of buyers relative to regular ones. An appropriate method is to use an amount corresponding to ten percent of annual sales. This figure is within the middle range for such expenses as reported earlier.

Before a distributor can start reselling a product purchased from a supplier, both must agree on the terms of the distribution agreement. That is why pre-market arrangement efforts are always mandatory when seeking to enter a new market or to add a product line. The costs related to these efforts, which represent the fourth component, can be very high for they include such costs as: traveling, entertainment, lodging, communication, costs of seeking and analyzing market information, cost of legal advice and the use of other experts and specialists involved in the distributor's decision making process. The time of negotiation and bargaining can go on for many years before an agreement is reached. Such is the reality for establishing a supplier distributor relationship. This is why pre-market development expenses can be very high. A lump sum is a more appropriate figure to use rather than one based on sales. Finally, other costs are also involved, and these deal with technical and sales training, setting up the service facilities for repairs and maintenance, preparing the technical manuals, and so forth. These costs, referred to as indirect selling expenses, cannot be estimated using a percentage of sales. Similar to the way pre-market development expenses are estimated, the same method can be used for arriving at a lump sum total for indirect selling costs incurred during the start-up phase.

To summarize, the following five expense components normally make up the various costs a wholesaler-distributor incurs when adding a new product line in his warehouses while also 
assuming the required product distribution tasks.

- lump sum for general and administrative expenses based as a percentage of the number of product lines handled

- a percentage of sales for all logistical expenses

- a percentage of sales for direct selling costs

- lump sum for pre-market development expenses

- $\quad$ lump sum for indirect selling expenses and other costs.

The addition of all these costs would no doubt show that the product line would not be profitable during the start-up phase, as predicted by the PLC. This phase may last anywhere from one to three years and is dependent, among other factors, on the length of time it took to arrive at a mutually acceptable selling arrangement (i.e., the initial contact phase up to signing the distribution agreement).

The costing procedure as outlined above illustrates very clearly that at least forty percent of sales achieved during the initial introductory phase are needed to cover some, but not all of the marketing costs involved in product distribution. The addition of the other three cost components will surely raise that percentage even higher. In fact, a fifty percent figure seems entirely plausible and probable.

\section{Conclusions}

This paper has outlined the role played by wholesaler-distributors in the economy, and in particular, on the marketing work they do for their suppliers. This paper is bringing back concepts that have been forgotten by the discipline over the years. A detailed list of marketing tasks was presented which served as the basis to estimate a distributor's start-up costs when handling a new product line and/or catering to a new class of customers. While no standard procedure exists in the marketing literature to estimate a distributor's start-up marketing costs, the use of logistical cost estimates and the PLC provided the means by which such costs could be calculated. The procedure showed that the marketing work performed by distributors in the initial phase of product distribution is higher than forty percent of sales, and may reach fifty percent or more during the first year, and up to and including the third year of business activity. As demonstrated in this paper, it is important to note that the agreement between the distributor and manufacturer is an important one and one which could be given more attention in future studies.

Of course, precise cost calculations of the marketing work done by distributors remains elusive, as we have already explained. However, the method presented here provides a good approximation of those true (i.e., theoretical) marketing costs.

\section{References}

Bartels, Robert. (1962). History of Marketing Thought, Irwin.

Beckman, Theodore and William Davidson. (1967). Marketing, 8th edition, Ronald Press. 
Berman, B. and A. P. Sharland. (2002). The teaching of relationship marketing concepts in undergraduate marketing principles and graduate introductory marketing courses, Journal of Marketing Education, Vol.24 (August), Iss. 2, pg. 125-135.

Brown, S. (2002). Reading Wroe: On the biopoetics of Alderson's functionalism, Marketing Theory, London, Vol. 2 (3), 243-272.

Day, G. (1981). The product life cycle: Analysis and applications issues, Journal of Marketing, Vol.45 (Autumn), pp 60-67.

Frazier, Gary L and Walfried Lassar. (1996). Determinants of distribution intensity, Journal of Marketing, Vol.60 (October), Iss. 4, pg. 39-52.

Gras, N.S.B. (1939). Business and Capitalism, An Introduction to Business History, NY: F.S. Crofts.

Gummesson, E. (2002). Practical value of adequate marketing management theory, European Journal of Marketing, Vol.36, Iss. 3, pg. 325-351.

Gundlach, G. and P. Bloom. (1998). Slotting allowances and the retail sale of alcohol beverages, Journal of Public Policy \& Marketing, Vol.17 (Fall), Iss. 2, pg. 173-185.

Grunert, K. and K. Ramus. (2005). Consumers' willingness to buy food through the internet: A review of the literature and a model for future research, British Food Journal, Vol. 107, Iss. 6, p. 381-404.

Hardy, Kenneth and Allan Magrath. (1988). Marketing Channel Management, Scott, Foresman and Company.

Hollander, Stanley. (1961). "Measuring the Cost and Value of Marketing", Business Topics, Vol. 9 (Summer), pp. 17-27.

Jensen, William. (1982). "Grocery Products Exhibit Different Life Cycle Curve", Marketing News, Vol. 16 (August 6), page 6.

Kimanyi, C. (2005). Wholesalers of Pharmaceutical Products: A Vibrant Industry, Canadian Economic Observer, Vol.18 (December), Iss. 12, pg. 3-11.

Koku, P.R. (2005). Towards an integrated marketing strategy for developing markets, Journal of Marketing Theory and Practice, Vol.13 (Fall), Iss. 4, pg. 8-22.

Kotler, Philip. (1972). Marketing Management, second edition, Prentice-Hall.

Kotler, Philip. (1976). Marketing Management, 3rd edition, Prentice-Hall.

Kotler, Philip, Gordon Mc Dougall and Gary Armstrong. (1988). Marketing Canadian Edition, Prentice-Hall Canada.

Lambert, Douglas. (1978). The Distribution Channels Decision, The Society of Management Accountants of Canada.

Lele, Milind. (1986). "Matching Your Channels to Your Product's Life Cycle", Business 
Marketing, Vol. 71 (December), pp. 61-69.

Lichtenthal, J. David and Leland Belk. (1984). "A History of the Definition of Marketing", in Jagdish Sheth (ed.), Research in Marketing, Vol. 7, JAI Press, pp. 133-163.

Major, M. (2006). Falling for it, Progressive Grocer. September 15, Vol. 85, Iss. 13, p. 76-81.

Manolis, Chris and J.B. Gassenheimer, R.D. Winsor. (2004). The moderating effect of solidarity as conduct: a theoretical and empirical perspective, Journal of Marketing Theory and Practice, Vol. 12 (Summer), Iss. 3, p. 48-61.

Mc Garry, E.D. (1950). "Some Functions of Marketing Reconsidered", in Reavis Cox and Wroe Alderson (eds.), Theory in Marketing, Irwin, pp. 263-279.

Mc Innes, William. (1964). "A Conceptual Approach to Marketing", in Reavis Cox, Wroe Alderson and Stanley Shapiro (eds.), Theory in Marketing, Irwin, pp. 51-67.

McVey, Phillip. (1960). "Are Channels of Distribution What the Textbooks Say?", Journal of Marketing, Vol. 24 (January), pp. 61-65.

Rosenbloom, Bert. (1987). Marketing Functions and the Wholesaler-Distributor: Achieving Excellence in Distribution, Distribution Research and Education Foundation.

Sharman, Graham (1984). "The Rediscovery of Logistics", Harvard Business Review, Vol. 62 (September-October). pp. 71-79.

Shaw Arch (1912). "Some Problems in Market Distribution", The Quarterly Journal of Economics, Vol. 26 (August), pp. 703-765.

Stern, Louis and Adel El-Ansary. (1992). Marketing Channels, 4th edition, Prentice-Hall.

Stock, James and Douglas Lambert. (1988). Strategic Logistics Management, second edition, Irwin.

Therrien, Louis. (1989). "Want Shelf Space at the Supermarket? Ante Up", Business Week, (August 7), pp. 60-61.

Thorelli, Hans and Stephen Burnett. (1981). "The Nature of Product Life Cycles for Industrial Goods Businesses", Journal of Marketing, Vol. 45 (Fall), pp. 97-108.

Webb, K. (2004). Multichannel distribution: an exploratory investigation of supplier firms' strategic motivation opportunities and challenges, American Marketing Association. Conference Proceedings, Vol. 15, pg 312.

\section{EXHIBIT 1}

\section{Marketing and Management Tasks}

\section{Performed by Distributors}

\section{$\underline{\text { 1. Sales Management Tasks }}$}

- National sales training sessions given to sales staff 


\section{Macrothink}

- On-going training to sales staff (local or from the national office)

- Sales staff supervision and evaluation

- Sales reports filled out by sales staff

- Sales reports filled out by sales managers

- Management of sales programs such as quotas, sales incentives, and bonuses

- Traveling, lodging, entertainment, and other expenses incurred by sales staff and analyzed by management

- Sales staff's routing and itinerary reports

- Sales meetings: local, regional, national

- Lost customers and complaints reports

- Sales staff's marketing kit (catalogs, videos, price lists, technical manual, etc.)

- Telemarketing sales personnel

- Prospecting new customers

- Making sales and sales contacts (negotiation, approval, etc.)

- Networking of sales staff

- Territorial sales plans

- Recruiting, hiring and firing of sales staff

2. Price or Financially-Related Tasks

- Leasing contracts and their management

- Customer invoice adjustments

- Management of discounts such as cash discounts, quantity discounts, seasonal or special

- Price schedules and revisions

- Payment schedule programs offered to customers

- Tax management responsibilities (GST, PST, customs and duties)

- Credit procedures for product returns, repairs done under warranty, etc.

\section{Logistics Tasks}

- Customer service requirements (time delays in processing or shipping an order)

- Inventory holding

- Billing, shipping and delivery 
- Order processing

- Transportation and routing schedules

- Warehousing and warehouse management

- Warehouse site location analysis

- In-house materials handling

- Packing and packaging requirements

- Inventory assistance given to suppliers and customers

- Establishment of communication systems for quick orders, inventory availability, or order status (EDI, FAX, 1-800, in house computer links with sales staff)

- Quick deliveries for certain customers

- Minimum order requirements

- Product returns guidelines

- Lot quantity, stockouts and reordering responsibilities

- Bulk making or bulk breaking tasks

- Product assortment availability

- Product returns and what to do with scrap, defective or obsolete products

\section{Advertising and Sales Promotion Tasks}

- Product literature, pamphlets, brochures

- Price lists

- Sales catalogues

- Sales aids given to sales staff

- Sales promotion material given to customers (calendars, gifts, pens, banners, agendas, etc.)

- Trade shows, trade booths requirements, conventions (national, international)

- Membership in trade groups, chambers of commerce, etc.

- Advertising in trade magazines or elsewhere

- Management seminars offered to suppliers or customers

- Event marketing (sponsoring activities for charity, goodwill, etc.)

- Cross promotional programs involving more than one supplier

- Promotional allowances given to end users 


\section{Macrothink}

- Fax, mail and other communication means to solicit orders

\section{Sales and Service}

- Establishment of repair and testing facilities (local and national)

- Repairs done on customers' premises

- Repairs done in shop

- Technical assistance provided to suppliers and customers

- Training of technicians in repairing and maintaining suppliers' products

- In-house product testing for durability and performance

- Issuance of guidelines as to product maintenance and repair requirements

- Warning guidelines issued to customers and suppliers as to defective parts or dangerous applications

\section{Market and Marketing Research}

- Sales forecasting efforts

- Sales staff's information gathering efforts

- Analysis of competition and competitive products

- Use of experts (consultants, lawyers, accountants)

- Interviews with suppliers, customers, and others for information analysis

- Industry sales analysis (imports, exports, etc.)

- Analysis of customer needs

- Analysis of product assortment to meet customer needs

- Search for new markets, new suppliers, or new product opportunities

- Price and pricing analysis, new leasing arrangements, etc.

\section{Sales and Sales Planning Tasks}

- Routinization of sales transactions with suppliers (direct links, fewer suppliers, etc.)

- Market coverage efforts (local and national)

- Exclusive dealings with suppliers or customers

- Tying sales arrangements with suppliers

- On site visits by suppliers

- Guaranty and warranty agreements 
- Access to product demonstrators, or on site use, product samples

- Analysis of customer satisfaction via market research

- Sales analysis by territory, product line, customer-type, by supplier

- Increased communication links between suppliers, sales staff, warehouses, and end users

Marketing and Management Tasks

\section{Performed by Distributors}

\section{$\underline{\text { 1. Sales Management Tasks }}$}

- $\quad$ National sales training sessions given to sales staff

- $\quad$ On-going training to sales staff (local or from the national office)

- $\quad$ Sales staff supervision and evaluation

- $\quad$ Sales reports filled out by sales staff

- $\quad$ Sales reports filled out by sales managers

- $\quad$ Management of sales programs such as quotas, sales incentives, and bonuses

- Traveling, lodging, entertainment, and other expenses incurred by sales staff and analyzed by management

- $\quad$ Sales staff's routing and itinerary reports

- $\quad$ Sales meetings: local, regional, national

- $\quad$ Lost customers and complaints reports

- $\quad$ Sales staff's marketing kit (catalogs, videos, price lists, technical manual, etc.)

- $\quad$ Telemarketing sales personnel

- $\quad$ Prospecting new customers

- $\quad$ Making sales and sales contacts (negotiation, approval, etc.)

- $\quad$ Networking of sales staff

- $\quad$ Territorial sales plans

- $\quad$ Recruiting, hiring and firing of sales staff

\section{Price or Financially-Related Tasks}

- $\quad$ Leasing contracts and their management

- $\quad$ Customer invoice adjustments

- Management of discounts such as cash discounts, quantity discounts, seasonal or special 
- $\quad$ Price schedules and revisions

- $\quad$ Payment schedule programs offered to customers

- $\quad$ Tax management responsibilities (GST, PST, customs and duties)

- $\quad$ Credit procedures for product returns, repairs done under warranty, etc.

\section{Logistics Tasks}

- $\quad$ Customer service requirements (time delays in processing or shipping an order)

- $\quad$ Inventory holding

- $\quad$ Billing, shipping and delivery

- $\quad$ Order processing

- $\quad$ Transportation and routing schedules

- Warehousing and warehouse management

- Warehouse site location analysis

- $\quad$ In-house materials handling

- $\quad$ Packing and packaging requirements

- Inventory assistance given to suppliers and customers

- $\quad$ Establishment of communication systems for quick orders, inventory availability, or order status (EDI, FAX, 1-800, in house computer links with sales staff)

- $\quad$ Quick deliveries for certain customers

- $\quad$ Minimum order requirements

- $\quad$ Product returns guidelines

- $\quad$ Lot quantity, stockouts and reordering responsibilities

- $\quad$ Bulk making or bulk breaking tasks

- $\quad$ Product assortment availability

- $\quad$ Product returns and what to do with scrap, defective or obsolete products

\section{Advertising and Sales Promotion Tasks}

- $\quad$ Product literature, pamphlets, brochures

- $\quad$ Price lists

- $\quad$ Sales catalogues

- $\quad$ Sales aids given to sales staff 
- Sales promotion material given to customers (calendars, gifts, pens, banners, agendas, etc.)

- $\quad$ Trade shows, trade booths requirements, conventions (national, international)

- $\quad$ Membership in trade groups, chambers of commerce, etc.

- $\quad$ Advertising in trade magazines or elsewhere

- $\quad$ Management seminars offered to suppliers or customers

- $\quad$ Event marketing (sponsoring activities for charity, goodwill, etc.)

- $\quad$ Cross promotional programs involving more than one supplier

- $\quad$ Promotional allowances given to end users

- $\quad$ 1-800, Fax, mail and other communication means to solicit orders

\section{Sales and Service}

- $\quad$ Establishment of repair and testing facilities (local and national)

- $\quad$ Repairs done on customers' premises

- $\quad$ Repairs done in shop

- $\quad$ Technical assistance provided to suppliers and customers

- Training of technicians in repairing and maintaining suppliers' products

- In-house product testing for durability and performance

- $\quad$ Issuance of guidelines as to product maintenance and repair requirements

- Warning guidelines issued to customers and suppliers as to defective parts or dangerous applications

\section{Market and Marketing Research}

- $\quad$ Sales forecasting efforts

- $\quad$ Sales staff's information gathering efforts

- $\quad$ Analysis of competition and competitive products

- $\quad$ Use of experts (consultants, lawyers, accountants)

- Interviews with suppliers, customers, and others for information analysis

- $\quad$ Industry sales analysis (imports, exports, etc.)

- $\quad$ Analysis of customer needs

- $\quad$ Analysis of product assortment to meet customer needs

- $\quad$ Search for new markets, new suppliers, or new product opportunities 


\section{Macrothink}

- $\quad$ Price and pricing analysis, new leasing arrangements, etc.

\section{Sales and Sales Planning Tasks}

- $\quad$ Routinization of sales transactions with suppliers (direct links, fewer suppliers, etc.)

- $\quad$ Market coverage efforts (local and national)

- $\quad$ Exclusive dealings with suppliers or customers

- $\quad$ Tying sales arrangements with suppliers

- $\quad$ On site visits by suppliers

- $\quad$ Guaranty and warranty agreements

- $\quad$ Access to product demonstrators, or on site use, product samples

- $\quad$ Analysis of customer satisfaction via market research

- $\quad$ Sales analysis by territory, product line, customer-type, by supplier

- Increased communication links between suppliers, sales staff, warehouses, and end users 